\title{
Methylation of human elongation factor eEF1A2 is not essential for eEF1A2-eEF1B interaction
}

\author{
L. V. Porubleva ${ }^{1}$, D. L. Kolesnik ${ }^{2}$, A. V. El'skaya ${ }^{1}$, B. S. Negrutskii ${ }^{1}$ \\ ${ }^{1}$ Institute of Molecular Biology and Genetics, NAS of Ukraine \\ 150, Akademika Zabolotnoho Str., Kyiv, Ukraine, 03143 \\ ${ }^{2}$ R. E. Kavetsky Institute of Experimental Pathology, Oncology and Radiobiology, NAS of Ukraine \\ 45, Vasilkivska Str., Kyiv, Ukraine, 03022 \\ negrutskii@imbg.org.ua,l.v.porubleva@imbg.org.ua
}

\begin{abstract}
Aim. Study on a possible role of methylation of lysine residues of eEF1A2 in its interactions with the elongation translation complex eEF1B. Methods. Mutagenesis, cloning, 293 human cell culture, BRET (bioluminescence resonance energy transfer), cell transfection, HaloTag pull down of protein complexes, Western blot, densitometry. Results. Five mutants of eEF1A2 with a single substitution of methylable lysine residue for arginine and the mutant with all five lysine residues mutated were generated. BRET analysis and HaloTag pull down experiments of isolated protein complexes have shown no differences in interactions of eEF1B subunits with eEF1A2 and its unmethylable mutants. Conclusion. Methylation of eEF1A2 apparently does not influence the interactions of eEF1A2 with eEF1B subunits.
\end{abstract}

K e y w o r d s: eEF1A2, eEA1B $\alpha$, eEA1B $\beta$, eEA1B $\gamma$, methylation, BRET, HaloTag.

\section{Introduction}

Translation elongation factor eEF1A*GTP carries aminoacyl-tRNA to the A-site of the 80 S ribosome facilitating the process of ribosomal protein synthesis. GTP hydrolysis finalizes the codon-anticodon recognition, then eEF1A*GDP leaves the ribosome [1]. The eEF1B complex comprising $\mathrm{B} \alpha, \mathrm{B} \beta$ and $\mathrm{B} \gamma$ subunits helps to exchange GDP for new GTP in eEF1A molecule $[2,3]$, that is why the
eEF1A-eEF1B interaction is very important for translation to proceed.

There are two tissue-specific isoforms of eEF1A with mutually exclusive expression patterns in the organism [4], which are characterized by different spatial organization $[5,6]$ and different ability to bind protein partners [7-9]. Both isoforms show the significant level of post-translational modifications [10-12].

C 2020 L. V. Porubleva et al.; Published by the Institute of Molecular Biology and Genetics, NAS of Ukraine on behalf of Biopolymers and Cell. This is an Open Access article distributed under the terms of the Creative Commons Attribution License (http://creativecommons.org/licenses/by/4.0/), which permits unrestricted reuse, distribution, and reproduction in any medium, provided the original work is properly cited 
eEF1A2 revealed oncogenic properties [13, 14]. An increased expression of eEF1B subunits was also found in different cancers $[15,16]$.

Methylation of lysine residues is an important modification involved in the regulation of cell activity. For instance, methylation of specific lysine residues in histones indorses binding of the proteins and induces transcriptional silencing [17]. On the other hand, methylation of lysine residues in histones can impede binding of effector molecules [18]. Methylation of lysine residues has been found in several nonhistone proteins, including transcription factors, receptors, ribosomal proteins, and translation factors [19-22]. A significant regulatory potential of this modification is emphasized by the discovery of demethylases, the enzymes that can remove a methyl group or several methyl groups from the already modified proteins [23]. Recent studies indicate the involvement of methylation/demethylation processes in both histone and non-histone proteins into oncogenesis [24-27].

Methylation of five conservative lysine residues of eEF1A (K36, K55, K79, K165 and $\mathrm{K} 318$ ) is known for more than 20 years [28]. A role of eEF1A methylation in tumorigenesis was recently suggested [29], however, the molecular mechanisms involved are not clear. Since all lysine residues of eEF1A capable of methylation are situated outside the protein globule $[30,31]$, we reasoned that methylation of these residues might affect the interaction of eEF1A with other proteins. eEF1B is one of the main translational partners of eEF1A during the elongation step of protein synthesis. Here, we study the effect of methylation of the proto-oncogenic eEF1A2 isoform on its interaction with eEF1B complex.

\section{Materials and Methods}

Cloning of eEF1A2 into plasmid $\mathrm{pFC} 14 \mathrm{~K}$ encoding HaloTag at the C-terminus of the target protein was performed using reagents and materials from the "HaloTag ${ }^{\circledR}$ Complete Pull-Down System" kit (Promega, USA). Amplification primers: 5'-GGCTGCGATCGCCATGGGAAAGGAAAAGACTCATAT-3' (direct) and 5'-GTCGGTTTAAACTTTAGCCTTCTGAGCTTTCT-3' (reverse). The composition of the PCR reaction mixture: matrix pcDNA3.1 (+)/eEF1A1 2 ng, 1x Phusion HF buffer, dNTP mixture $200 \mu \mathrm{M}$, primers 25 pmol, Phusion High-Fidelity DNA polymerase (Thermo Scientific, USA) 1 unit. PCR amplification conditions: initial denaturation $98^{\circ} \mathrm{C} 30 \mathrm{~s}$, denaturation $98^{\circ} \mathrm{C} 30 \mathrm{~s}$, annealing $61^{\circ} \mathrm{C} 10 \mathrm{~s}$, elongation $72^{\circ} \mathrm{C} 21 \mathrm{~s}, 30$ cycles, final elongation $72^{\circ} \mathrm{C} 10 \mathrm{~min}$. The PCR product was transformed into competent $\mathrm{E}$. coli XL10 Gold cells. The plasmid was isolated using the GeneJet ${ }^{\mathrm{TM}}$ MiniPrep Purification Kit (Thermo Scientific, USA) according to the manufacturer's method. The identity of the obtained plasmid was verified by restriction using FD HindIII (Thermo Scientific, USA).

Directed mutagenesis was performed by PCR by the Quick change method (Stratagene, [32]). The primers for replacement of lysine residues by arginine in eEF1A2:

1A2-K36R-Direct: 5'CAAATGCGGAGGTATTGACAGAAGGACCATTGAGAAGTTC 3'

1A2-K36R-Reverse: 5' GAACTTCTCAATGGTCCTTCTGTCAATACCTCCGCATTTG 3' 1A2-K55R-Direct: 5' GAAGGGATCCTTCAGGTATGCCTGGGTG 3'

1A2-K55R-Reverse: 5' CACCCAGGCATACCTGAAGGATCCCTTC 3' 
1A2-K79R-Direct: 5' GACATCTCCCTCTGGAGGTTCGAGACCACCAAG 3'

1A2-K79R-Reverse: 5' CTTGGTGGTCTCGAACCTCCAGAGGGAGATGTC 3'

1A2-K165R-Direct: 5' CCTACAGCGAGAGGCGCTACGACG 3',

1A2-K165R-Reverse: 5' CGTCGTAGCGCCTCTCGCTGTAGG 3'

1A2-K318R-Direct: 5' CGTGTCGGTGAGGGACATCCGGC 3'

1A2-K318R-Reverse: 5' GCCGGATGTCCCTCACCGACACG 3'

The composition of the PCR reaction mixture: matrix pFC14K/eEF1A2 $10 \mathrm{ng}$, 1x Phusion HF buffer, dNTPs $200 \mu \mathrm{M}, \mathrm{MgCl}_{2}$ $2.3 \mathrm{mM}$, primers 25 pmol, Phusion HighFidelity DNA polymerase (Thermo Scientific, USA) 2 units. PCR amplification conditions: initial denaturation $98^{\circ} \mathrm{C} 3 \mathrm{~min}$, denaturation $98^{\circ} \mathrm{C} 12 \mathrm{~s}$, annealing $72^{\circ} \mathrm{C} 30 \mathrm{~s}$, elongation $72^{\circ} \mathrm{C} 3 \mathrm{~min}, 18$ cycles, final elongation $72^{\circ} \mathrm{C}$ $10 \mathrm{~min}$. For matrix restriction, the PCR mixture was incubated with $1 \mu$ of restriction enzyme DpnI at $37^{\circ} \mathrm{C}$ overnight and deactivated by heating at $65^{\circ} \mathrm{C}$ for $20 \mathrm{~min}$.

Cells 293 were grown at $37^{\circ} \mathrm{C}, 5 \% \mathrm{CO}_{2}$, $100 \%$ humidity in DMEM containing $5 \%$ FBS and antibiotics penicillin and streptomycin and glutamine. Transfection of 293 cells with plasmids $\mathrm{pFC} 14 \mathrm{~K} / \mathrm{eEF} 1 \mathrm{~A} 2$, pFC14K/ eEF1A2(KxxR) and control vector HaloTag was performed with TurboFect reagent (Thermo Scientific, USA) for $24 \mathrm{~h}$, after which cells were pelleted, lysed using mammalian lysis buffer (Promega, USA) at $-80^{\circ} \mathrm{C}$ until use. Affinity purification of partner proteins was performed using the HaloTag ${ }^{\circledR}$ Complete Pull-Down System (Promega, USA) according to the manufacturer's instructions. Proteins were separated in $10 \%$ PAGE for expression control of HaloTag-eEF1A2(KxxR). Proteins from lysates separated by SDS-PAGE were transferred to PVDF membrane (Hybond-P) at $30 \mathrm{~V}$ for $30 \mathrm{~min}$. The membrane was then blocked for $1 \mathrm{~h}$ at room temperature in $5 \%$ dried nonfat milk in Tris-buffered saline. After blocking, the membranes were incubated with primary antibodies (1:10000 rabbit anti-HaloTag, Promega, USA) in $3 \%$ dried non-fat milk in $1 \mathrm{X}$ Tris-buffered saline with $0.1 \%$ Tween $20(\mathrm{v} / \mathrm{v}, \mathrm{TBST})$ overnight at $4^{\circ} \mathrm{C}$. After washing with $1 \mathrm{X}$ TBST, the membrane was incubated with anti-rabbit IgG-HRP (1:5000) secondary antibody in $3 \%$ dried nonfat milk in $1 \mathrm{X}$ TBST or anti-mouse antibody (1:10000) in $3 \%$ dried nonfat milk in $1 \mathrm{X}$ TBST for $1 \mathrm{~h}$ at room temperature. ECL was used to visualize bands probed with HRP secondary antibody (Amersham Biosciences ECL Prime). The gel was photographed on a ChemiDoc tool (BioRad, USA). Densitometry was performed using ImageLab software (BioRad, USA).

Interactions of eEF1A2 and its mutants with eEF1B $\alpha$ by BRET method were analyzed with NanoBRET ${ }^{\mathrm{TM}}$ Protein:Protein Interaction System (Promega, USA) [33]. eEF1B $\alpha$ was cloned into pNLF1 plasmid (Promega, USA). The used primers are: 5'AGTAGAATTCGTAATGGGTTTCGGAGACCTGAAAAG 3' (direct) and 5' AGTGTCTAGATTAGATCTTGTTGAAAGCAGCCAC 3'(reverse). The composition of the PCR reaction mixture: matrix $\mathrm{pET} / \mathrm{eEF} 1 \mathrm{~B} \alpha 2 \mathrm{ng}, 1 \mathrm{x}$ Phusion HF buffer, dNTP mixture $200 \mu \mathrm{M}$, primers 25 pmol, Phusion High-Fidelity DNA polymerase (Thermo Scientific, USA) 1 unit. PCR amplification conditions: initial denaturation $98^{\circ} \mathrm{C}$ $30 \mathrm{~s}$, denaturation $98^{\circ} \mathrm{C} 12 \mathrm{~s}$, annealing $64^{\circ} \mathrm{C}$ 
$15 \mathrm{~s}$, elongation $72^{\circ} \mathrm{C} 12 \mathrm{~s}, 30$ cycles, final elongation $72^{\circ} \mathrm{C} 10 \mathrm{~min}$. The PCR product and pNLF1 plasmid were restricted with FD EcoRI and FD XbaI (Thermo Scientific, USA), ligated with T4 DNA Ligase (HC) (Promega, USA). The product of ligation was transformed into competent E. coli XL10 Gold cells. The plasmid was isolated using the GeneJet TM MiniPrep Purification Kit (Thermo Scientific, USA) according to the manufacturer's method. The identity of the obtained plasmid was verified by restriction using FD EcoRI and FD XbaI (Thermo Scientific, USA).

The Control Vector plasmid (Promega, USA) expressing the HaloTag alone was used as a negative control. 300000 cells 293 were plated into a well of a 12-well plate and were grown overnight in DMEM medium at $37^{\circ} \mathrm{C}$, $5 \% \mathrm{CO}$. After the attachment to wells the cells were transfected with TurboFect reagent (Thermo Scientific, USA) by plasmids $2 \mu \mathrm{g}$ HaloTag plasmid - pFC14K/eEF1A2 or its mutants or HaloTag Control Vector and $0.02 \mu \mathrm{g}$ NanoLuc Plasmid pNLF1/eEF1B $\alpha$ (ratio $100: 1)$. In 24 hours the cells were replanted into 96-well plate $\left(2 \times 10^{5}\right.$ cells/well $)$ in OptiMEM ${ }^{\circledR}$ I Reduced Serum Medium, no phenol red (Life Technologies, USA) $+4 \%$ FBS, containing $100 \mathrm{nM}$ HaloTag ${ }^{\circledR}$ NanoBRET $^{\mathrm{TM}}$ 618 Ligand or $0.1 \%$ DMSO. Cells were incubated at $37^{\circ} \mathrm{C}, 5 \% \mathrm{CO}_{2}$ overnight $(18$ 24 hours). $5 \mathrm{X}$ solution of NanoBRETTM NanoGlo $^{\circledR}$ Substrate in Opti-MEM ${ }^{\circledR}$ I Reduced Serum Medium without phenol red was added to each well up to $1 \mathrm{x}$ final dilution immediately before measurement. Donor emission $(460 \mathrm{~nm})$ and acceptor emission $(618 \mathrm{~nm})$ were measured using plate reader Synergy HT (BioTek Instrument, USA).

\section{Results and Discussion}

To investigate the role of methylation of several specific Lys residues in eEF1A2 we produced the mutant proteins where these residues were replaced by Arg. Five mutants with a single substitution, K36R, K55R, K79R, K165R or K318R, were generated. "Full" mutant (FM) was also produced, in which all five indicated Lys residues were replaced by Arg. Arg cannot be methylated by methyltrasferases specific for Lys and the replacement of Lys by Arg should not cause significant conformational changes in the protein, since Arg retains a positive charge of the Lys side chain. Here, the energy transfer and pull down approaches were applied to investigate the interaction of these mutants with different subunits of the eEF1B complex.

The mutant and wild-type eEF1A2 proteins were cloned into plasmid $\mathrm{pFC} 14 \mathrm{~K}$ encoding HaloTag. The tag was located at the C-terminus of eEF1A2, since a majority of the Lys residues of interest were confined to the N-terminal part of the protein. In this case, HaloTag would not create steric hindrance to the interaction with the partner proteins. The resulting plasmid encoded eEF1A2-HaloTag with a molecular weight of about $85 \mathrm{kDa}(50 \mathrm{kDa}$ eEF1A2 and $35 \mathrm{kDa}$ HaloTag).

To estimate a possible effect of the eEF1A2 methylation on its interaction with eEF1B in intracellular environment we used a bioluminescence resonance energy transfer (BRET) system. The interaction between the two fusion proteins, one of which carries luminescent label and another contains fluorescent label, can make these labels close enough for the resonance energy transfer to occur. In this case, we used bioluminescent NanoLuc luciferase 
(Promega, USA) fused with $\mathrm{eEF} 1 \mathrm{~B} \alpha$ and a fluorescent ligand linked to HaloTag in eEF1A2.

293 cells were transfected with the plasmids encoding wild-type eEF1A2 and its mutants containing HaloTags and eEF1B $\alpha$ fused with the NanoLuc domain. Fig. 1 shows that BRET between eEF1A2-HaloTag and nanoLuc$\mathrm{eEF} 1 \mathrm{~B} \alpha$ is easily detected evidencing the existence of eEF1A2-eEF1B interaction in 293 cells. Importantly, no methylation-deficient mutants showed a difference at the BRET level as compared to wild-type eEF1A2. It implies that methylation of the Lys residues in positions $36,55,79,165$ and 318 of eEF1A2 may have no significant impact on its interaction with the eEF1B complex in human cells.

However, it remains possible that we could not detect the methylation effect due to some limitations of the BRET method, which provides measurements directly in cells. Additionally, we used only one subunit of eEF1B for BRET experiments. So, we employed the
HaloTag-based pull down procedure to test if we could observe a difference in the wild type and mutant eEF1A2 proteins binding to different subunits of eEF1B in cell lysates by Western blotting.

The HaloTag® Pull-Down system was used for pull down experiments. The amount of Halo label in the lysates of cells expressing different proteins with HaloTag was estimated by Western blotting with anti-HaloTag antibodies. Then the HaloTag affinity purification system for protein complexes was used to pull down the protein partners of eEF1A2. The proteins were separated by polyacrylamide gel electrophoresis. Noteworthy, before starting the pull down procedure the volume of each electrophoresis sample was adjusted to correspond to the normalized amount of eEF1AHaloTag, measured by Western blot of the cell lysates with anti-HaloTag antibodies (Fig. 2). Besides, to control the level of binding of HaloTag protein to the resin, the portions of cell lysates after exhausting by pull down were

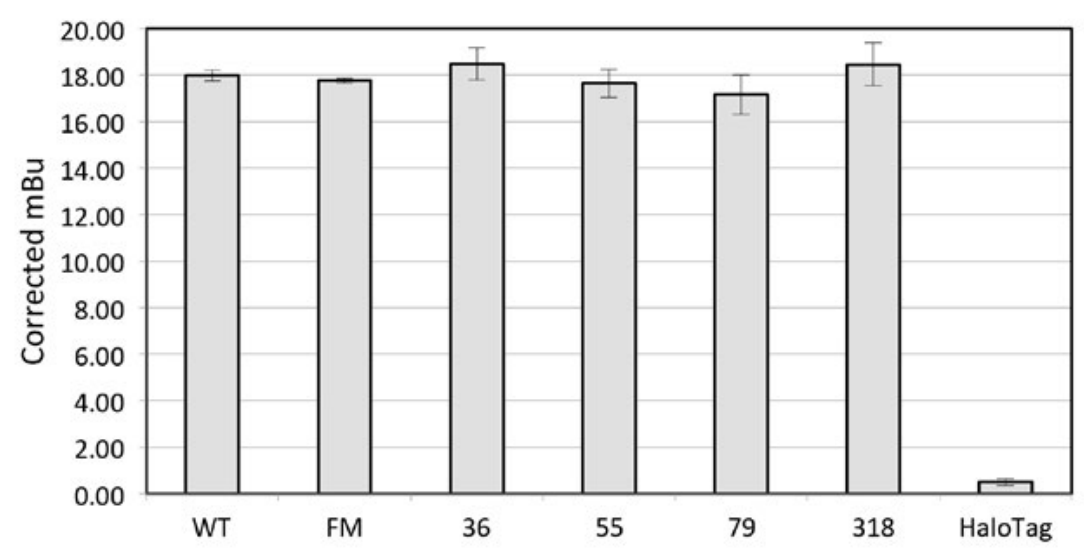

Fig. 1. BRET analysis of interactions NanoLuc-eEF1B $\alpha$ and eEF1A2-HaloTag or its mutants. BRET data were analyzed with MaxStat Lite software. The diagram represents an average of three experiments + standard deviation. Signatures: WT: eEF1A2 (WT); 36: eEF1A2(K36R); 55: eEF1A2(K55R); 79: eEF1A2(K79R); 318: eEF1A2(K318R); FM: full mutant eEF1A2; HaloTag: HaloTag Control Vector. 


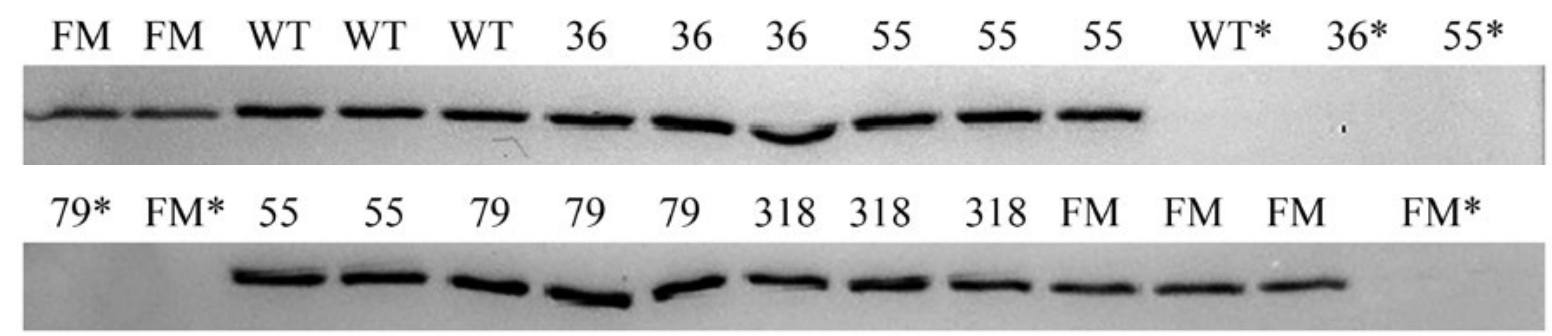

Fig. 2. Comparative analysis of the proteins expression levels in 293 cells after transfection with plasmids carrying WT eEF1A2 or its mutants fused to HaloTags. $10 \mu 1$ of each cell lysate were loaded on PAAG in triplicate. Average values of the densities were used for calculation of eluate volumes to be loaded on PAAG for Western blot analysis with HaloTag antibodies. eEF1A2(K318R)-HaloTag; FM: full mutant eEF1A2-HaloTag. WT*, 36*, 55*,79*, FM* same as before but the samples were taken after pull down procedure.

loaded on the same gel. This was necessary to ensure the correct comparison of the protein levels in each sample. Western blots with the antibodies recognizing eEF1B $\alpha$, eEF1B $\beta$ and eEF1B $\gamma$ subunits were subjected to densitometry to quantitate the subunits levels in the eluates of the pulled down proteins.
Densitometry analysis of the blots confirmed the interaction of eEF1B subunits with eEF1A2 (Fig. 3). It should be kept in mind that eEF1A is capable to interact directly with the eEF1B $\alpha$ and eEF1B $\beta$ subunits whereas an apparent interaction of eEF1A with eEF1B $\gamma$, observed on Western blots, in fact just reflects
$\boldsymbol{A}$

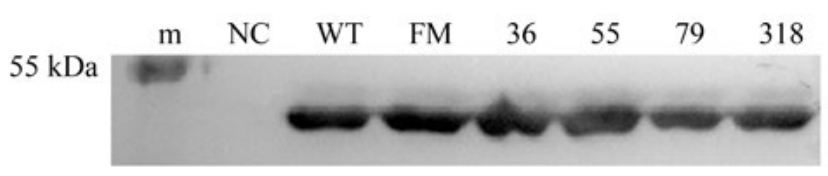

$\boldsymbol{B}$

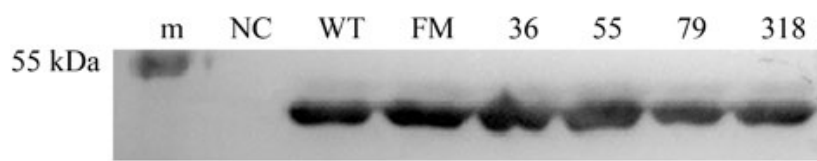

C

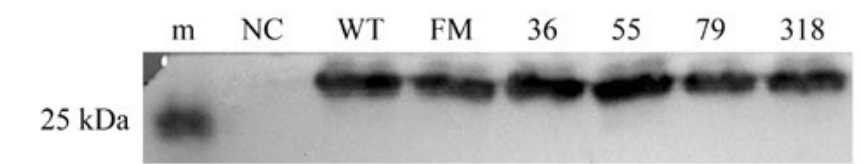

D

\begin{tabular}{c|c|c|c}
\hline & eEF1B alpha & eEF1B beta & eEF1B gamma \\
\hline WT & 100 & 100 & 100 \\
\hline FM & 90 & 109 & 118 \\
\hline 36 & 116 & 84 & 127 \\
\hline 55 & 120 & 124 & 117 \\
\hline 79 & 79 & 110 & 101 \\
\hline 318 & 88 & 98 & 92 \\
\hline
\end{tabular}

Fig. 3. Western blots of pull-down eluates with antibodies against eEF1B $\gamma(\mathrm{A}), \mathrm{eEF} 1 \mathrm{~B} \beta(\mathrm{B})$, eEF1B $\alpha$ (C). (D) - densitometry data. $m$ - Protein weight markers, $\mathrm{NC}$ - negative control, HaloTag Control Vector; WT - eEF1A2(WT)HaloTag; 36 - eEF1A2 (K36R)-HaloTag; 55 eEF1A2(K55R)-HaloTag; 79 eEF1A2(K79R)-HaloTag; 318 eEF1A2(K318R)-HaloTag; FM - full mutant eEF1A-HaloTag. As the levels of expression of HaloTag-linked eEF1A2 or its mutants after transfection could be slightly different, the loading volumes of pulled down fractions were adjusted to correspond to an equal amount of HaloTag protein bait, according to Fig. 2 . 
eEF1A binding to other subunits of the eEF1B complex [34]. Thus, in the case of eEF1B $\gamma$, we actually observed the interaction of eEF1A2 with the eEF1B complex. Again, no essential changes in the amount of the eEF1B $\alpha, \mathrm{eEF} 1 \mathrm{~B} \beta$ and eEF1B $\gamma$ subunits pulled down by the methylation-free mutants were detected as compared to wild-type eEF1A2 (Fig. 2). The mutant K165R was not studied in this case, as K165 methylation did not influence the interactions of eEF1A with other elongation factors in pull down procedure [35]. Thus, methylation of eEF1A2 apparently has no substantial effect on its interaction with the eEF1B complex both in vitro and in cellular.

After identification of five methyltransferases of eEF1A that are unique for every lysine residue involved [29, 36-38] it became clear that eEF1A is the only known so far target of these enzymes. It is known that methylation of K55 in eEF1A may be important for tumorigenesis $[29,39]$ but a potential mechanism of the impact of K55 as well as of K36, $\mathrm{K} 79, \mathrm{~K} 165$ and K318 methylation remains to be elucidated. As the methylated Lys residues are localized on the surface of the eEF1A proteins one may suggest that this modification may influence the interaction of eEF1A with the protein partners. eEF1A has a number of confirmed translational $[40,41]$ and non-translational [7, 8, 42-44] protein partners, thus the search for methylation-impacted protein-protein contacts is at the initial stage.

Our data suggest a removal of the altered eEF1A2-eEF1B interaction from the list of potential molecular mechanisms explaining how the methylation influences a tumorigenic action of eEF1A2. As far as translation is concerned, methylation of eEF1A2 may be still important for its interaction with ribosomal proteins $[45,46]$ and/or aminoacyl-tRNA synthetases [47]. Besides, eEF1A2 fulfills a number of moonlighting functions [48], so methylation may have an impact on the eEF1A2 interaction with different non-translational proteins in cancer cells.

This work was supported in part by the budget program KPKVK 6541230, project №0120U100648.

\section{REFERENCES}

1. Negrutskii B, Vlasenko D, Mirande M, Futernyk $P$, El'skaya A. mRNA-Independent way to regulate translation elongation rate in eukaryotic cells. IUBMB Life. 2018;70(3):192-96.

2. Le Sourd F, Boulben S, Le Bouffant R, Cormier P, Morales $J$, Belle R, Mulner-Lorillon O. eEF1B: At the dawn of the 21 st century. Biochim Biophys Acta. 2006;1759(1-2):13-31.

3. Trosiuk TV, Shalak VF, Szczepanowski RH, Negrutskii BS, El'skaya AV. A non-catalytic N-terminal domain negatively influences the nucleotide exchange activity of translation elongation factor $1 \mathrm{~B} \alpha$. FEBS J. 2016;283(3):484-97.

4. Newbery HJ, Loh DH, O'Donoghue JE, Tomlinson VA, Chau YY, Boyd JA, Bergmann JH, Brownstein D, Abbott CM. Translation elongation factor eEF1A2 is essential for post-weaning survival in mice. J Biol Chem. 2007;282(39):28951-59.

5. Novosylna AV, Timchenko AA, Tiktopulo EI, SerdyukI, Negrutskii BS, El'skaya AV. Characterization of physical properties of two isoforms of translation elongation factor 1A, Biopolym. Cell. 2007; 23(5):386-90.

6. Timchenko AA, Novosylna OV, Prituzhalov EA, Kihara H, El'skaya AV, Negrutskii BS, Serdyuk IN. Different oligomeric properties and stability of highly homologous A1 and proto-oncogenic A2 variants of mammalian translation elongation factor eEF1. Biochemistry. 2013;52(32):5345-53.

7. Novosylna O, Jurewicz E, Pydiura N, Goral A, Filipek A, Negrutskii B, El'skaya A. Translation 
elongation factor eEF1A1 is a novel partner of a multifunctional protein Sgt1. Biochimie. 2015;119:137-45.

8. Novosylna O, Doyle A, Vlasenko D, Murphy M, Negrutskii B, El'skaya A. Comparison of the ability of mammalian eEF1A1 and its oncogenic variant eEF1A2 to interact with actin and calmodulin. Biol Chem. 2017;398(1):113-24.

9. Li Z, Wang Y, Qiu J, Li Q, Yuan C, Zhang W, Wang D, Ye J, Jiang H, Yang J, Cheng $J$. The polycomb group protein EZH2 is a novel therapeutic target in tongue cancer. Oncotarget. 2013;4(12): 2532-49.

10. Kahns S, Lund A, Kristensen P, Knudsen CR, Clark BF, Cavallius J, Merrick WC. The elongation factor 1 A-2 isoform from rabbit: cloning of the cDNA and characterization of the protein. Nucleic Acids Res. 1998;26:1884-90.

11. Soares DC, Barlow PN, Newbery HJ, Porteous DJ, Abbott CM. Structural models of human eEF1A1 and eEF1A2 reveal two distinct surface clusters of sequence variation and potential differences in phosphorylation. PLoS One. 2009;4(7):e6315.

12. Negrutskii B, Vlasenko D, El'skaya A. From global phosphoproteomics to individual proteins: the case of translation elongation factor eEF1A. Expert Rev Proteomics. 2012;9(1):71-83.

13. Anand N, Murthy S, Amann G, Wernick M, Porter LA, Cukier IH, Collins C, Gray JW, Diebold J, Demetrick DJ, Lee JM. Protein elongation factor EEF1A2 is a putative oncogene in ovarian cancer. Nat Genet.2002; 31(3):301-5.

14. Kobayashi D, Tokuda T, Sato K, Okanishi H, Nagayama M, Hirayama-Kurogi M, Ohtsuki S, Ara$k i N$. Identification of a specific translational machinery viaTCTP-EF1A2 interaction regulating NF1associated tumor growth by affinity purification and data-independent mass spectrometry acquisition (AP-DIA). Mol Cell Proteomics. 2019;18(2):245-62.

15. Veremieva $M$, Khoruzhenko A, Zaicev $S$, Negrutskii $B$, El'skaya $A$. Unbalanced expression of the translation complex eEF1 subunits in human cardioesophageal carcinoma. Eur J Clin Invest. 2011;41(3):269-76.

16. Veremieva $M$, Kapustian L, Khoruzhenko $A$, Zakharychev V, Negrutskii B, El'skaya A. Indepen- dent overexpression of the subunits of translation elongation factor complex eEF1H in human lung cancer. BMC Cancer. 2014;14:913.

17. Li D, Rawle DJ, Wu Z, Jin H, Lin MH, Lor M, Abbott $C M$, Harrich $D$. eEF1A demonstrates paralog specific effects on HIV-1 reverse transcription efficiency. Virology. 2019;530:65-74.

18. Chen S, Yang Z, Wilkinson AW, Deshpande AJ, Sidoli S, Krajewski K, Strahl BD, Garcia BA, Armstrong SA, Patel DJ, Gozani $O$. The PZP domain of AF10 senses unmodified H3K27 to regulate DOT1L-mediated methylation of H3K79. Mol Cell. 2015;60(2):319-27.

19. Biggar KK, Li SS. Non-histone protein methylation as a regulator of cellular signalling and function. Nat Rev Mol Cell Biol. 2015;16(1):5-17

20. Egorova KS, Olenkina OM, Olenina LV. Lysine methylation of nonhistone proteins is a way to regulate their stability and function. Biochemistry (Mosc). 2010;75(5):535-48.

21. Morgunkova A, Barlev NA. Lysine methylation goes global. Cell Cycle. 2006;5(12), 1308-12.

22. Polevoda B, Sherman F. Methylation of proteins involved in translation. Molecular Microbiology. 2007; 65(3), 590-606.

23. Shi Y, Lan F, Matson C, Mulligan P, Whetstine JR, Cole PA, Casero RA, Shi Y. Histone demethylation mediated by the nuclear amine oxidase homolog LSD1. Cell. 2004; 119(7):941-53.

24. Black JC, Manning AL, Van Rechem C, Kim J, Ladd B, Cho J, Pineda CM, Murphy N, Daniels DL, Montagna C, Lewis PW, Glass K, Allis CD, Dyson NJ, Getz G, Whetstine JR. KDM4A lysine demethylase induces site-specific copy gain and rereplication of regions amplified in tumors. Cell. 2013;154(3):541-55.

25. Faria JA, Corrêa NC, de Andrade C, de Angelis Campos AC, Dos Santos Samuel de Almeida R, Rodrigues TS, de Goes AM, Gomes DA, Silva FP. SET domain-containing protein 4 (SETD4) is a newly identified cytosolic and nuclear lysine methyltransferase involved in breast cancer cell proliferation. J Cancer Sci Ther. 2013 Jan 21;5(2):58-65.

26. Kudithipudi S, Jeltsch A. Role of somatic cancer mutations in human protein lysine methyltransferases. Biochim Biophys Acta. 2014;1846(2):366-79. 
27. Wang L, Yamaguchi S, Burstein MD, Terashima K, Chang $K$, Ng HK, Nakamura H, He Z, Doddapaneni H, Lewis L, Wang $M$, Suzuki T, Nishikawa R, Natsume A, Terasaka S, Dauser R, Whitehead W, Adekunle A, Sun J, Qiao Y, Marth G, Muzny DM, Gibbs RA, Leal SM, Wheeler DA, Lau CC. Novel somatic and germline mutations in intracranial germ cell tumours. Nature. 2014;511(7508):241-45.

28. Dever TE, Costello CE, Owens CL, Rosenberry TL, Merrick $W C$. Location of seven post-translational modifications in rabbit elongation factor 1 alpha including dimethyllysine, trimethyllysine, and glycerylphosphorylethanolamine. $J$ Biol Chem. 1989;264(34):20518-25.

29 Liu S, Hausmann S, Carlson SM, Fuentes ME, Francis JW, Pillai R, Lofgren SM, Hulea L, Tandoc K, Lu J, Li A, Nguyen ND, Caporicci M, Kim MP, Maitra A, Wang H, Wistuba II, Porco JA Jr, Bassik MC, Elias JE, Song J, Topisirovic I, Van Rechem C, Mazur PK, Gozani O. METTL13 methylation of eEF1A increases translational output to promote tumorigenesis. Cell. 2019;176(3):491-504.

30. Crepin T, Shalak VF, Yaremchuk AD, Vlasenko DO, McCarthy A, Negrutskii BS, Tukalo MA, El'skaya AV. Mammalian translation elongation factor eEF1A2: X-ray structure and new features of GDP/GTP exchange mechanism in higher eukaryotes. Nucleic Acids Res. 2014;42(20):12939-48.

31. Kanibolotsky DS, Novosyl'na OV, Abbott CM, Negrutskii BS, El'skaya AV. Multiple molecular dynamics simulation of the isoforms of human translation elongation factor $1 \mathrm{~A}$ reveals reversible fluctuations between "open" and "closed" conformations and suggests specific for eEF1A1 affinity for $\mathrm{Ca} 2+-$ calmodulin. BMC Struct Biol. 2008;8:4.

32. Weiner MP, Costa GL, Schoettlin W, Cline J, Mathur E, Bauer JC. Site-directed mutagenesis of double-stranded DNA by the polymerase chain reaction. Gene. 1994;151(1-2):119-23.

33. Machleidt T, Woodroofe CC, Schwinn MK, Méndez J, Robers MB, Zimmerman K, Otto P, Daniels DL, Kirkland TA, Wood KV. NanoBRET-A Novel BRET platform for the analysis of proteinprotein interactions. ACS Chem Biol. 2015;10(8): 1797-804.
34. Negrutskii B. Non-translational connections of eEF1B in the cytoplasm and nucleus of cancer cells. Front Mol Biosci. 2020;7:56.

35. Malecki J, Aileni VK, Ho AYY, Schwarz J, Moen A, Sørensen V, Nilges BS, Jakobsson ME, Leidel SA, Falnes $P \emptyset$. The novel lysine specific methyltransferase METTL21B affects mRNA translation through inducible and dynamic methylation of Lys165 in human eukaryotic elongation factor 1 alpha (eEF1A). Nucleic Acids Res. 2017;45(8):4370-89.

36. Hamey JJ, Wilkins MR. Methylation of Elongation Factor 1A: Where, Who, and Why? Trends Biochem Sci. 2018;43(3):211-23.

37. Jakobsson ME, Matecki J, Falnes PØ. Regulation of eukaryotic elongation factor 1 alpha (eEF1A) by dynamic lysine methylation. RNA Biol. 2018;15(3):314-19.

38. Jakobsson ME, Matecki JM, Halabelian L, Nilges BS, Pinto R, Kudithipudi S, Munk S, Davydova E, Zuhairi FR, Arrowsmith CH, Jeltsch A, Leidel SA, Olsen JV, Falnes PØ. The dual methyltransferase METTL13 targets N terminus and Lys55 of eEF1A and modulates codon-specific translation rates. Nat Commun. 2018;9(1):3411.

39. Xiao $S$, Wang Y, Ma Y, Liu J, Tang C, Deng $A$, $F a n g$. Dimethylation of eEF1A at lysine 55 plays a key role in the regulation of eEF1A2 on malignant cell functions of acute myeloid leukemia. Technol Cancer Res Treat. 2020;19:1533033820914295.

40. Cao Y, Portela M, Janikiewicz J, Doig J, Abbott CM. Characterisation of translation elongation factor eEF1B subunit expression in mammalian cells and tissues and co-localisation with eEF1A2. PLoS One. 2014;9(12):e114117.

41. Lukash TO, Turkivska HV, Negrutskii BS, El'skaya $A V$. Chaperone-like activity of mammalian elongation factor eEF1A: renaturation of aminoacyl-tRNA synthetases.Int $J$ Biochem Cell Biol. 2004;36(7):1341-1347.

42. Grund A, Szaroszyk M, Korf-Klingebiel M, Malek Mohammadi M, Trogisch FA, Schrameck U, Gigina A, Tiedje C, Gaestel M, Kraft T, Hegermann J, Batkai S, Thum T, Perrot A, Remedios CD, Riechert E, Völkers $M$, Doroudgar S, Jungmann A, Bauer R, Yin X, Mayr M, Wollert KC, Pich A, 
Xiao H, Katus HA, Bauersachs J, Müller OJ, Heineke J. TIP30 counteracts cardiac hypertrophy and failure by inhibiting translational elongation. EMBO Mol Med. 2019;11(10):e10018.

43. Chan $H Y$. Expanded polyalanine tracts function as nuclear export signals and promote protein mislocalization via eEF1A1 factor. $J$ Biol Chem. 2017;292(14):5784-5800.

44. Li S, Feng $S$, Wang JH, He WR, Qin HY, Dong $H$, Li LF, Yu SX, Li Y, Qiu HJ. eEF1A Interacts with the NS5A Protein and Inhibits the Growth of Classical Swine Fever Virus. Viruses. 2015;7(8):45634581.

45. Shao S, Murray J, Brown A, Taunton J, Ramakrishnan V, Hegde RS. Decoding Mammalian RibosomemRNA States by Translational GTPase Complexes. Cell. 2016;167(5):1229-40.

46. Klassen $R$, Schaffrath $R$. Collaboration of tRNA modifications and elongation factor eEF1A in decoding and nonsense suppression. Sci Rep. 2018;8(1):12749.

47. Petrushenko ZM, Budkevich TV, Shalak VF, Negrutskii BS, El'skaya AV. Novel complexes of mammalian translation elongation factor eEF1A.GDP with uncharged tRNA and aminoacyl-tRNA synthetase. Implications for tRNA channeling. Eur J Biochem. 2002;269(19):4811-18.

48. Sasikumar AN, Perez WB, Kinzy TG. The many roles of the eukaryotic elongation factor 1 complex. Wiley Interdiscip Rev RNA. 2012;3(4):543-55.

\section{Метилування фактора елонгації трансляції людини еEF1A2 не впливас на взасмодію eEF1A2-eEF1B.}

Л. В. Порубльова, Д. Л. Колесник, Г. В. Сльська, Б. С. Негруцький.

Мета. 3'ясування впливу метилування лізинових залишків фактора елонгації трансляції еEF1A2 на взаємодію із субодиницями елонгаційного комплексу еЕF1B. Методи. Мутагенез, клонування, культивування клітин людини 293, трансфекція клітин, BRET (резонанс трансферу біолюмінісцентної енергії), афінна очистка білкових комплексів, Вестерн блот, денситометрія.
Результати. Отримані п'ять мутантів еEF1A2, в яких один з п'яти консервативних лізинових залишків, здатних до метилування, замінений на аргінін, та один мутант, в якого мутовані всі п'ять лізинів. Результати BRET та Вестерн блот аналізу виділених білківпартнерівеЕF1A2 показали відсутність суттєвих відмінностей у взаємодії еEF1A2 і його мутантів, не здатних до метилування, із субодиницями елонгаційного комплексу еEF1B. Висновки. Метилування лізинових залишків еEF1А2, вочевидь, не впливає на взаємодію із субодиницями елонгаційного комплексу еЕF1B.

Ключов і слова: eEF1A2, eEA1B $\alpha$, eEA1B $\beta$, eEA1B $\gamma$, метилування, BRET, HaloTag.

\section{Метилирование фактора элонгации трансляции человека EEF1A2 не влияет на взаимодействие еЕF1А2-еEF1B.}

Л. В. Порублёва, Д. Л. Колесник, А. В. Ельская, Б. С. Негруцкий.

Цель. Выяснение влияния метилирования лизиновых остатков фактора элонгации трансляции еEF1A2 на взаимодействие с субъединицами элонгационного комплекса еEF1B. Методы. Мутагенез, клонирование, культивирование клеток человека 293, трансфекция клеток, BRET (резонанс трансфера биолюминисцентной энергии), аффинная очистка белковых комплексов, Вестерн блот, денситометрия. Результаты. Получены пять мутантов еEF1A2, в которых один из пяти метилируемых консервативных лизиновых остатков, заменен на аргинин, и один мутант, у которого мутированы все пять лизинов. Результаты BRET и Вестерн блот анализа выделенных белков-партнеров еEF1A2 не показали существенных различий во взаимодействии eEF1A2 и его неметилируемых мутантов с субъединицами элонгационного комплексаеЕF1B. Выводы. Метилирование лизиновых остатков еЕF1А2, по-видимому, не влияет на взаимодействие с субъединицами элонгационного комплекса еEF1B.

Ключевые слова: eEF1A2, eEA1B $\alpha$, eEA1B $\beta$, eEA1B $\gamma$, метилирование, BRET, HaloTag.

Received 03.06.2020 